\title{
Recalibration or "regurgitation"?
}

Published at www.cmaj.ca on Mar. 4

I $\mathrm{n}$ one respect, it was hard to imagine a more quintessential expression of Conservative ideology than the third Speech from the Throne delivered in the 40th session of Parliament on Mar. 3.

As expected, the wide-ranging address delivered by Governor-General Michaëlle Jean offered such free-market prescriptions for the economy as lifting foreign investment restrictions in select industries and reducing the regulatory burden for corporations.

Yet, somewhat surprisingly, Prime Minister Stephen Harper's policy blueprint included a raft of specific offerings designed to "recalibrate" the Conservatives direction and image, including promises to "bolster" the federal Science \& Technology strategy, to make safe drinking water and effective waste-water treatment treatment on native reserves a priority, to continue elite-level funding for athletes and to increase the universal child care benefit (currently $\$ 100$ per month) for single parents.

The overall tenor of the Throne Speech, though, was to signal that budget cuts are coming. And, in a classic political move, to lay the groundwork for restraint by setting an example, Harper announced that the government will freeze the administrative budgets of departments and the salaries of ministers and members of Parliament.

Also as expected, the Throne Speech, entitled "A Strong Canada. A Strong Economy. Now and in the Future," reinforced the "get tough on crime" agenda that has captivated the governing Conservatives, including promises to increase penalties for sex offences against children and give police "investigative powers for the twenty-first century."

And also as expected, the Throne Speech offered nothing in the way of additional resources for health care, except to reinforce that the government would not breach the provisions of the

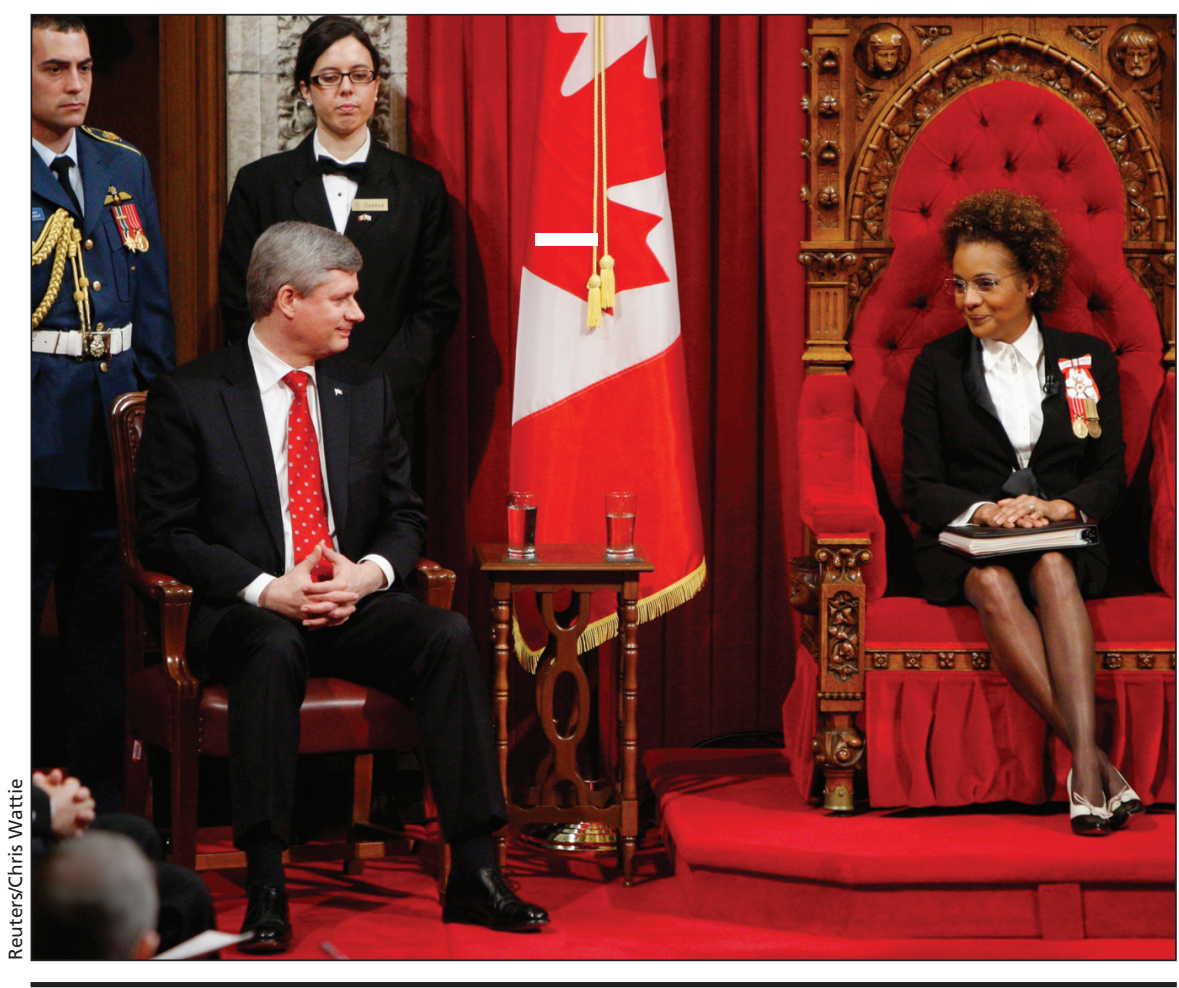

Governor-General Michaëlle Jean sits after deliving the Speech from the Throne, while Prime Minister Harper looks on in the Senate chamber on Parliament Hill.

2004 federal-provincial health care agreement, the 10-Year Plan to Strengthen Health Care, which stabilizes federal transfers for health through 2014.

Although it's widely believed that a minority government would not dare to cut federal health transfers to the provinces in the face of a possible election, the commitment will reassure those who feared that any near-term efforts to balance the nation's books would involve the health care sector. But deficit reduction "will not come by cutting transfer payments for health care and education or by raising taxes on hard-working Canadians," the speech vowed. "These are simply excuses for a federal government to avoid controlling spending."

Indeed, the promise to leave federal transfers untouched was reassuring, as was the commitment to ensure that the government will "meet the demands of aging population," says Canadian
Healthcare Association President Pamela Fralick.

But as with all throne speeches, "the devil will be in the details," with regard to other promises, such as establishment of a childhood injury prevention strategy and the rather unusual vow to "look to innovative charities and forward-thinking private-sector companies to partner on new approaches to many social challenges."

"I'm really curious as to what that means," Fralick says. "Will that be interpreted as downloading some of the responsibilities that we would see requiring federal leadership or does the partner word in that bullet truly mean it's going to be a positive way of doing things differently, moving forward?

Other health-related promises, along with the expansion of the universal child care benefit, included vows to reintroduce consumer product safety legislation "in its original form," as 
well as a commitment to "continue to strengthen Canada's food safety system ... to ensure that families have the information they need to make informed choices and it will hold those who produce, import and sell goods in Canada accountable for the safety of Canadians."

The government also vowed to enhance financial support for training initiatives and to "expand the opportunities for our top graduates to pursue post-doctoral studies and to commercialize their ideas."

While hinting that it would bolster funding for research, the government also promised to "launch a digital economy strategy to drive the adoption of new technology across the economy. To encourage new ideas and protect the rights of Canadians whose research, development and artistic creativity contribute to Canada's prosperity, our Government will also strengthen laws governing intellectual property and copyright."

The government's attempt, though, to recalibrate itself as a government of innovation was largely dismissed by Opposition politicians.

"It's regurgitation," charged Liberal Party Leader Michael Ignatieff, adding that the blueprint also fell short as a strategy to constrain government spending. "This is not a serious strategy to reduce the deficit," he told reporters.
The broad economic focus of the Throne Speech appeared largely predicated upon principles articulated in Advantage Canada, Building a Strong Economy for Canadians, a strategy crafted in 2006 to simultaneously promote economic growth and reduce the national debt (www.fin.gc.ca/ec2006 /pdf/plane.pdf), and Compete to Win, the report of the Competition Policy Review Panel (www.ic.gc.ca/eic/site/cprp-gepmc .nsf/vwapj/Compete_to_Win.pdf/\$FILE /Compete_to_Win.pdf).

Both strategies broadly favoured approaches based on establishing the so-called "right" macroeconomic conditions for industry to flourish, such as low business tax rates, limited regulation and eased restrictions on the level of foreign ownership in key economic sectors, while also advocating some measure of government investment in training and infrastructure.

Advantage Canada, crafted by the Department of Finance, urged that public sector research and development investments be bolstered by "investing in research equipment and facilities in universities and colleges to compete with the best in the world; increasing graduate scholarship support, including for the sciences and engineering; and exposing more students to private sector research challenges through internships and targeted collaborative research." It also urged that public sec- tor research be more responsive to business needs or targeted at areas "where Canada has the potential to be a world leader, such as energy, environmental technologies and health sciences."

Compete to Win, crafted by an Industry Canada-appointed panel headed by Lynton Ronald Wilson, former president of Bell Canada Enterprises and former vice-chairman of the Royal Bank of Canada, is broadly based on the proposition that Canadian companies will be able to compete on global markets if the government removes "legal, regulatory and policy impediments to competition."

It urged lower barriers to foreign investment and foreign ownership levels in sectors of the economy such as transportation, communications and, to a lesser extent, financial services. As well, it advocated lower corporate tax rates and investments in training, along with far closer ties between universities and industry. "Governments should use all the mechanisms at their disposal to encourage post-secondary education institutions to collaborate more closely with the business community, cultivating partnerships and exchanges in order to enhance institutional governance, curriculum development and community engagement," the report recommended. - Wayne Kondro, CMAJ

DOI:10.1503/cmaj.109-3200 